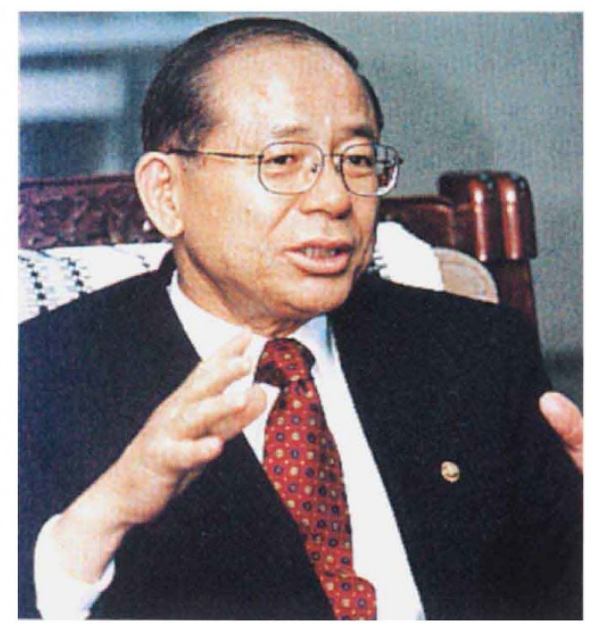

Kwun: will steer new science legislation

\section{Physicist takes top Korean science post}

[SEOUL] South Korea has replaced its science minister for the third time in eight months. Last week, President Young-Sam Kim appointed Sook-il Kwun, a professor of physics and former dean of science at Seoul National University, to head the Ministry of Science and Technology.

Senior science advisers to the Korean government expressed relief that the ministry is once again in the hands of a scientist with a sound understanding of the importance of basic research. One of Kwun's key tasks will be to push forward new legislation for the promotion of science and technology.

The proposed law, already in draft form, is modelled partly on the basiclaw for science and technology passed recently in Japan. But, with presidential elections due next February, Kwun will have less than a year in office to see the law passed.

Kwun's appointment is part of a cabinet shake-up following a series of scandals that has rocked Kim's government. Kwun replaces Yong-jin Kim, who served barely two months before getting embroiled in a scandal over his role in extending bank loans to the debt-ridden Hanbo business group in his former position as head of the Office of Bank Supervision.

Yong-jin Kim had succeeded Pon-young Koo, an economist who was promoted to become the senior representative of South Korea at the Organization of Economic Cooperation and Development only a few months after he had replaced KunMo Chung as science minister last August. Chung was serving his second term as science minister and had been in office for more than a year a comparatively long period of office in South Korea these days. He is one of the founding fathers of South Korea's first graduate university, the Korea Advanced Institute of Science and Technology (see Nature 364, 379; 1993).

DavidSwinbanks

\title{
California agency charged with delaying toxin reports
}

[SAN FRANCISCO] California's environmental research agency was accused last week of diluting and delaying scientific reports that may have led to stricter regulations on potentially dangerous chemicals. The accusations were made by university scientists, former employees and environmental activists in testimony before the state legislature.

Their concern reflects fears expressed by legislators when the agency was established in 1991 about the dangers of shifting responsibility for public health and scientific risk assessment from the Department of Health Services to the California Environmental Protection Agency. The legislators were worried that political appointees might interfere with the scientific operations of the office to justify particular policy initiatives.

Last week's hearing was called by Senator Byron Sher (Democrat, Palo Alto) in response to complaints that the Office of Environmental Health Hazard Assessment (OEHHA) had inappropriately interfered with and altered public risk assessments of environmental toxins.

The office was also accused of quashing various studies, including one on airborne pesticides, and allowing its budget to decline to a precarious level. "We thought it was important to have a hearing and give the director a chance to respond," Sher said.

At the hearing before the Senate Committee on Environmental Quality, university scientists who review OEHHA's work complained that reports on environmental tobacco smoke, lead and vehicle emissions had been watered down by state employees and held up for several years.

Representatives of the Natural Resources
Defense Council, an environmental group, identified 70 chemicals known to cause birth defects or cancer about which it claimed the state had failed to warn the public.

The senators also heard allegations that OEHHA was cutting back on staff to a crippling level and that it had terminated several important studies, including one on the impact of pesticide drift on the number of hospital admissions of patients with asthma in Lompoc, California.

Richard Becker, director of the OEHHA, said in response that he was committed to sound scientific analysis, promptly delivered, and that tensions in his office were the result of his demands for greater openness, greater objectivity and a closer look at all possible mechanisms and modes of action of particular chemicals.

He said the state had already issued warnings on some 583 toxic chemicals, and would continue to carry out its mandate to warn the public about dangerous chemicals.

But Sher said after the hearing that he was convinced that the problems at the agency were real, and expressed particular concern about pressure from outside interests such as lead industry representatives - who may have contributed to the three-year delay on thelead report. He asked Becker for information to explain the cause of the hold-up.

The report on lead's health risks to children and adults was released last October after five years of preparation; the report on environmental tobacco smoke, which was issued two weeks ago, took six years to complete; and a study on the health risks of diesel exhaust has been in preparation for more than four years.

SallyLehrman

\section{CERN raises funds for antimatter detector}

[MUNICH] Drawing on substantial support from Japan, CERN, the European Laboratory for Particle Physics, is to build an experimental facility, the Antiproton Decelerator, to study the characteristics of antihydrogen and other exotic atoms.

The decelerator will cost SFr7 million (US\$4.7 million). Japan is contributing at least half of the costs of building the machine, and will also spend a further SFr10 million on a major antimatter research project to be carried out using it. The facility will be built by transforming an existing machine at CERN, the Antihydrogen Collector, which collected the first antihydrogen atoms ever detected, produced by the now-defunct LEAR (low-energy antiproton ring) facility in 1995.
Budgetary restrictions had threatened the development of this pioneering work, which was repeated more recently at Fermilab in the United States. But CERN announced this week that a fund collected from countries including Denmark, Germany, Italy, Japan, Poland and the United States, will allow physicists to explore whether a world made entirely of antimatter would have exactly the same characteristics as the world of matter.

The opportunity will allow CERN to carry out particle physics experiments in the five-year period after its major accelerator, the Large Electron-Positron collider, is switched off and before its successor, the Large Hadron Collider, comes into operation. 